\title{
REPRESENTASI PEREMPUAN DALAM CERBUNG LELAKI JAHANAM \\ KARYA NOVIE PURWANTI DI KOMUNITAS BISA MENULIS (ANALISIS WACANA KRITIS)
}

\author{
WOMEN REPRESENTATION IN NOVIE PURWATIS'S \\ SERIAL STORY LEKAKI JAHANNAM \\ IN KOMUNITAS BISA MENULIS (CRITICAL DISCOURCE ANALYSIS)
}

Dian Uswatun Hasanah, Syahroma Eka Suryani

UIN Raden Mas Said Surakarta

Jalan Pandawa Dusun III, Pucangan, Kecamatan Kartasura, Kabupaten Sukoharjo, Jawa Tengah

Ponsel: 085642035333,Pos-el: dianneuh@gmail.com,syahromaekas@gmail.com

\begin{abstract}
Abstrak
Cerita bersambung Lelaki Jahanam karya Novie Purwanti banyak menampilkan gambaran perempuan yang termarjinalkan, terkurung dalam budaya patriarki dan persoalan lain yang dihadapi perempuan dalam rumah tangga. Permasalahan seperti demikian dekat dengan realita kehidupan saat ini. Penelitian ini bertujuan untuk mendeskripsikan representasi perempuan dalam cerita bersambung Lelaki Jahanam karya Novie Purwanti di grup media sosial Facebook, yaitu Komunitas Bisa Menulis (KBM). Metode penelitian yang digunakan dalam penelitian ini adalah deskriptif kualitatif dengan analisis wacana kritis prespektif Fairclough. Wacana, paragraf dan dialog dalam cerita bersambung dianalisis bagaimana ideologi turut merepresentasikan perempuan. Dari hasil penelitian tentang representasi perempuan dalam cerbung Lelaki Jahanam dapat disimpulkan bahwa terdapat tiga representasi yang ditemukan, yaitu representasi perempuan dilihat dari pengaruh gender, representasi perempuan dalam melawan patriarki, dan representasi perempuan dilihat dari status sosial.
\end{abstract}

Kata Kunci: representasi; perempuan; analisis wacana kritis; cerita bersambung

\section{Abstract}

The Serial story of Lelaki Jahanam by Novie Purwanti depicts many women who are marginalized, locked up in a patriarchal culture and other problems in the household. Such problems are close to the realities of woman's life today. This study aims to describe the representation of women in the story of Lelaki Jahanam by Novie Purwanti in the Facebook social media group, the Komunitas Bisa Menulis (KBM). 
The research method used is descriptive-qualitative method with critical discourse analysis from Fairclough's perspective. Discourse, paragraphs and dialogue in a serial story are analyzed to see how ideology represents women. Results of the research about women's representation in Cerbung "Lelaki Jahanam" are concluded into three representation. namely those women are represented based on their gender, those are represented to act against patriarchy, and those are represented under their social status.

Keywords: representation; woman; critical discourse analysis; serial story

\section{Pendahuluan}

Tantangan dalam dunia kepenulisan saat ini semakin besar. Disadari atau tidak, era digital memiliki peran utama terhadap permasalahan ini. Seperti yang ditekankan oleh Irfan Azizi dalam artikel Republika.co.id (dalam Kelana, 2018) bahwa merebaknya smartphone dan munculnya aplikasi-aplikasi digital sangat berdampak pada dunia kepenulisan. Lebih lanjut Irfan Azizi menyatakan bahwa saat ini banyak penulis yang popular meski tidak mempunyai karya berbentuk buku. Mereka menulis dengan cara mengunggah tulisan mereka melalui media-media online seperti Wattpad, grup-grup menulis, blog pribadi, dan lainlain. Penulis yang menempuh jalan ini tak selalu penulis pemula. Justru, banyak di antara mereka yang notabenenya adalah penulis senior.

Banyaknya media online tentu saja memberi angin segar bagi para penulis. Semakin sering penulis mengunggah karya dan semakin berkualitas karya yang dihasilkan, akan semakin banyak pembaca (follower) yang mengikutinya. Hal ini semakin menunjukkan eksistensi penulis dalam dunia kepenulisan.

Salah satu media online facebook yang menjadi wadah bagi para penulis adalah grup Komunitas Bisa Menulis (KBM). Kehadiran grup KBM di jagat kepenulisan tidak bisa dipandang sebelah mata. KBM adalah forum terbuka untuk belajar menulis yang dibuat oleh Isa Alamsyah, suami dari penulis ternama Indonesia, Asma Nadia. Grup ini sudah ada sejak tahun 2004. Sampai detik ini, anggota grup KBM sudah mencapai lebih dari satu juta anggota. Keberadaan KBM di media sosial fecebook ternyata telah memberi banyak manfaat bagi para penulis. Selain karya-karya semakin dikenal luas, pada akhirnya banyak penerbit yang "meminang" karya penulis dari grup tersebut untuk dibukukan. Pertimbangan utama dari penerbit untuk dibukukan karena karya-karya penulis dalam grup tersebut berkualitas dan 
mendapat apresiasi yang baik dari anggota grup.

Tema-tema yang diangkat para penulis di grup KBM cukup bervariasi mulai dari genre komedi, horor, percintaan, remaja, bahkan tema-tema dewasa. Biasanya, para penulis di KBM akan mengunggah karya-karya dengan tema yang aktual, memenuhi selera pasar.

Tema yang mengangkat konflik seputar perempuan cukup banyak disuguhkan penulis dan mendapat tempat tersendiri di hati para pembaca KBM. Tema ini menarik untuk dikaji, mengingat bahwa perempuan adalah objek yang tidak luput dari perbincangan di bidang ekonomi, politik, sosial, budaya, agama, bahkan pada karya sastra. Micarina, dalam Kompasiana (2015) menyebutkan, sebagian besar tema karya sastra mengangkat perempuan sebagai objek kajian dalam puisi, roman, cerpen, novel, dan lain-lain. Bahkan dalam sejarah sastra Indonesia, keberadaan perempuan memiliki pengaruh sebagai salah satu menu utama yang paling banyak dipilih. Sastra memberikan gambaran kehidupan, potret fenomena sosial, kejadian yang secara konkret terjadi di masyarakat, atau kenyataan sosial.

Setiap jenis tulisan, sangat dipengaruhi oleh ideologi penulisnya. Hal ini berlaku juga dalam tulisan-tulisan di grup KBM, yang sebagian besar memang ditulis oleh penulis perempuan. Di sini, para penulis perempuan seakan-akan berlomba untuk menyuarakan ideologi mereka tentang permasalahan yang kerap menimpa kaum perempuan, termasuk di antaranya adalah gender dan ideologi patriarki yang masih ada di masyarakat.

Berpijak dari permasalahan tersebut, peneliti tertarik untuk mengungkapkan bagaimana representasi perempuan dalam cerita bersambung di Komunitas Bisa Menulis. Adapun cerbung yang akan diteliti yaitu Lelaki Jahanam karya Novie Purwanti. Novie Purwanti merupakan penulis produktif di media sosial baik Facebook maupun Whattpad yang karyanya telah banyak diterbitkan. Karya-karya Novie Purwanti banyak diwarnai oleh tema perempuan dan gender. Karya-karyanya seperti Lelaki Jahanam (terbit di Biru Magenta 2018), Agasri (terbit di Hazerain Publisher 2018), Minta Kawin (terbit di Hazerain Publisher 2019), serta tulisan bersatatus on going di Whattpad seperti Rearen, Curhat Pengantin Baru, Derai Maya, dan Zina.

Peneliti mengambil cerbung Lelaki Jahanam karena cerbung tersebut mengangkat tema yang berkaitan dengan 
kehidupan sosial perempuan saat ini. Banyak narasi yang ditampilkan melalui penggambaran perempuan misalnya, kilas kehidupan perempuan kota yang penuh kebebasan dan problematika yang dihadapi perempuan dalam rumah tangga. Permasalahan-permasalahan seperti demikian dekat dengan realitas kehidupan saat ini yang diungkapkan melalui kisah oleh pengarang.

Sebagaimana pernyataan Rampan (dalam Sugihastuti \& Saptiawan, 2010: 81) bahwa karya sastra berperan sebagai wujud ungkapan pengarang terhadap permasalahan yang ditemui di masyarakatnya. Masalah-masalah realita sosial itulah kemudian diangkat menjadi teks sastra oleh pengarang yang dimodifikasi sedemikian rupa agar berbeda dengan kenyataan empiris. Sehingga dpat dikatakan bahwa realita sosial yang ditampilkan melalui teks sastra adalah refleksi permasalahan sosial yang terjadi di lingkungan masyarakat. Lebih lanjut lagi Rampan (dalam Sugihastuti \& Saptiawan, 2010: 82) meyatakan bahwa dalam karya sastra juga digambarkan mengenai pola-pola sosial masyarakat, peran dan fungsi setiap anggota masyarakat serta interaksi antaranggota masyarakat. Pada dasarnya dalam teks sastra juga menampilkan unsur masyarakat, yaitu laki-laki dan perempuan. Unsur tersebut memiliki perbedaan dalam hal hubungan, peran dan fungsi maupun dalam tatanan sosial masyrarakat.

Sugihastuti \& Saptiawan (2010: 82) menyatakan bahwa relasi antara laki-laki dan perempuan digambarkan dalam berbagai bentuk pola perilaku yang merefleksikan penerimaan dari laki-laki maupun perempuan terhadap kedudukan masing-masing jenis kelamin. Pola tersebut kemudian diperkuat adanya realita pada masyarakat bahwa kedudukan laki-laki lebih unggul dibandingkan perempuan. Hal semacam itu terus berkembang hingga memunculkan stereotip bahwa perempuan adalah kaum lemah sedangkan laki-laki adalah kuat dan memilki kekuasaan.

Penelitian ini bertujuan untuk mendeskripsikan representasi perempuan dalam cerbung Lelaki Jahanam. Penelitian ini akan diarahkan pada kajian analisis wacana kritis. Dalam analisis wacana kritis, bahasa memiliki peran untuk mengintepretasikan makna suatu wacana. Analisis wacana kritis juga erat kaitannya dengan sistem bahasa yang digunakan pada konteks sosial. Pada analisis wacana kritis, bahasa tidak ditempatkan secara tertutup, akan tetapi 
juga memerhatikan bagaimana peran ideologi dalam membentuk wacana.

Penelitian yang berkaitan dengan representasi perempuan dan analisis wacana kritis pernah dilakukan oleh Sanusi dan Bahfiarti (2018) dengan judul Representasi Perempuan dalam Film Dangal (Sebuah Analisis Diskursus Kritis) dimuat di Jurnal Komunikasi KAREBA. Jurnal tersebut membicarakan representasi perempuan India dalam film Dangal yang dibandingkan dengan fakta yang terjadi di lingkup sosial budaya perempuan Indonesia. Sanusi \& Bahfiarti (2018) menggunakan teknis analisis wacana kritis melalui pendekatan Norman Fairclough. Hasil penelitiannya menunjukkan bahwa ada perkembangan bentuk emansipasi perempuan India karena prestasi maskulinitas yang diraih oleh tokoh perempuan melelui kontes gulat dunia. Hal tersebut membuat masyarakat India yang masih menganut sistem patriarki menjadi lebih terbuka pandangannya bahwa perempuan juga dapat bersaing di luar urusan domestiknya sebagai perempuan. Emansipasi seperti demikian juga ditemukan di Indonesia dengan realitas kondisi yang lebih didukung daripada perempuan India.

Penelitian serupa dengan penelitian penulis adalah tesis mahasiswi UIN
Sunan Kalijaga, Mahmudah (2019) dengan judul Penggambaran Perempuan Arab Saudi oleh Media Daring (Analisis Wacana Kritis Fairclough pada Media Al-Jazair Online dan Al-Madina). Penelitian tersebut memaparkan gambaran perempuan Arab dari tiga dimensi Norman Fairclough, yaitu tekstual, praktik diskursus, dan praktik sosiokultural. Penelitian yang dilakukan Mahmudah (2019) memperoleh hasil bahwa media memberitakan perempuan Arab Saudi sejalan dengan transformasi visi Saudi 2030 mendatang yakni hukum kontemporer.

Dari kedua penelitian yang relevan tersebut, persamaanya adalah mengungkap representasi perempuan menggunakan analisis wacana kritis prespektif Fairclough. Adapun perbedaanya terletak pada objek penelitian. Penulis menggunakan teks cerita bersambung dalam salah satu grup menulis di Facebook yang permasalahnnya erat dengan realita kehidupan perempuan saat ini.

\section{Landasan Teori}

\subsection{Representasi}

Teori representasi menurut Struat Hall (dalam Aprinta E.B, 2011: 16) mempunyai dua pemaknaan, yaitu representasi mental dan representasi 
dalam bentuk bahasa. Representasi mental diartikan sebagai suatu pikiran tentang sesuatu yang ada di benak setiap orang dan bersifat abstrak, sedangkan representasi bahasa memiliki peran penting pada pengonstruksian makna. Gagasan atau pemikiran abstrak yang ada dalam benak manusia perlu ditafsirkan melalui bahasa, sehingga konsep-konsep atau ide tentang suatu tanda tersebut dapat saling dihubungkan.

Aprinta E.B (2011:16) mengambil kesimpulan bahwa representasi merupakan proses sosial dengan dimaknai melalui sistem tanda seperti teks, dialog, fotografi, vidio, film, dan lainnya. Representasi juga dikatakan sebagai proses penciptaan makna dengan sistem bahasa.

Pendapat tentang representasi juga dikemukkan oleh Isnaniah, (2014: 31-32) bahwa representasi berkaitan dengan anggapan atau stereotip yang melekat pada perempuan. Kemunculan konsep representasi dapat menempati peranan yang penting dalam ilmu kebudayaan. Representasi merupakan bagian inti dari suatu proses yang dapat menghasilkan makna serta dapat dipertukarkan di bagian kebudayaan. Representasi sendiri memiliki peranan untuk menghubungkan makna dan bahasa dalam kebudayaan.
Arti dari representasi maksudnya adalah bahwa representasi dalam mengungkapkan sesuatu yang memiliki makna tentang dunia yang banyak makna pada orang lain dengan cara menggunakan bahasa. Tidak hanya menggunakan bahasa saja, dalam representasi juga memerlukan simbol, tanda, dan gambar-gambar untuk merepresentasikan sesuatu. Graeme Burton (dalam Prasanti \& Janitra, 2016: 48) mengatakan bahwa pada dasarnya representasi merujuk pada bagaimana seseorang mendefinisikan kelompok tertentu.

Surahman (2014: 43--22) menyatakan bahwa secara singkat representasi adalah salah satu cara untuk menciptakan makna. Ada dua komponen penting yang bekerja pada proses penciptaan makna, yaitu konsep pikiran dan bahasa. Konsep tentang sesuatu hal diolah oleh akal pikiran manusia, sehingga manusia dapat menafsirkan makna atas suatu hal tersebut.

Listyarini (dalam Irawan, 2014) menambahkan, representasi berkaitan dengan sistem sosial yang diciptakan atas kesadaran manusia. Ketika melakukan komunikasi antarsesamanya, manusia menggunakan simbol atau tanda untuk berkomunikasi. Representasi dapat 
berubah-ubah sesuai dengan kemunculan pandangan baru pada hidup manusia.

\subsection{Analisis Wacana Kritis}

Analisis wacana kritis yang dikemukakan Fairclough

menunjuk pada penggunaan bahasa sebagai aktivitas sosial, bukan hanya sebatas aktivitas individu saja. Fairclough juga menciptakan model analisis wacana kritis dengan menghubungkan analisis wacana berdasarkan linguistik dan berdasarkan sosial-politik. Secara umum model seperti ini dihubungkan pada perubahan sosial.

Setiawan \& Halum (2016: 173) menarik benang merah dari pendapat yang dikemukakan oleh Fairclough dan Wodak bahwa analisis wacana erat kaitannya dengan studi tentang bahasa. Kendati demikian, pada analisis wacana kritis, pemahaman mengenai wacana tidak hanya terfokus pada analisis bahasa berdasarkan gambaran aspek kebahasaan saja, tetapi dihubungkan dengan konteks bahasa yang digunakan untuk tujuan tertentu.

$$
\text { Fairclough (1996) berpendapat }
$$
bahwa pendekatan analisis wacana kritis berkontribusi pada pemahaman tentang hubungan kekuasaan dan ideologi dalam wacana. Lisnawati, (2017: 67) juga berkesimpulan bahwa analisis wacana kritis berkaitan dengan sistem bahasa yang digunakan pada konteks sosial. Penggunaan bahasa tersebut bertujuan untuk meneliti kekuasaan, ketidaksetaraan, ketidakadilan, kekuatan dan prasangka sebagai bentuk permasalahan guna menemukan solusi atas permasalahan tersebut.

Fairclough dan Wodak menyatakan bahwa pada analisis wacana kritis bahasa ditempatkan sebagai faktor penting, yaitu terkait dengan peran dan fungsi bahasa dalam mendeskripsikan ketimpangan kekuasaan pada masyarakat. Analisis wacana kritis menyelidiki bagaimana melalui bahasa kelompok sosial yang ada saling bertarung (Eriyanto, 2001). Ada lima karakteristik dalam analisis wacana kritis, pertama adalah prinsip tindakan. Pada prinsip pertama, wacana dipahami sebagai suatu tindakan atau bentuk interaksi. Pemahaman seperti ini tergantung bagaimana cara pandang terhadap wacana. Ada dua cara pandang terhadap wacana, pertama wacana sebagai sesuatu yang mengandung tujuan misalnya membujuk, mempengaruhi, mengajak dan sebagainya. Kedua, wacana sebagai sesuatu yang diekspresikan secara sadar dan terkontrol.

Kedua adalah konteks. Pada prinsip kedua ini, konteks wacana seperti latar, 
peristiwa, dan situasi juga dipertimbangkan dalam analisis wacana kritis. Konteks memasukkan semua situasi dan hal yang berada di luar teks dan mempengaruhi pemakaian bahasa seperti siapa pertisipan bahasa, dimana dan bagaimana teks itu diproduksi, serta maksud dari fungsi itu.

Ketiga adalah prinsip historis. Pada prinsip ini wacana ditempatkan sebagai konteks sosial tertentu. Aspek terpenting untuk memahami teks yaitu wacana ditepatkan pada konteks historis tertentu. Paham atau tidaknya terhadap wacana pada suatu teks akan didapatkan setelah menempatkan konteks historis di mana teks itu diciptakan.

Keempat adalah prinsip kekuasaan. Elemen kekuasaan juga dipertimbangkan pada analisis wacana kritis. Elemen ini merupakan kunci hubungan antara wacana dan masyarakat, yaitu pada fungsi kontrol. Melalui wacana, satu orang dengan orang yang lain saling memberikan kontrol secara psikis maupun mental. Selain itu, wujud kontrol juga dapat berupa kontrol atas konteks yang mudah diindra, yaitu siapa yang diperbolehkan bicara, atau siapa yang hanya mendengarkan atau mengiyakan saja.
Kelima yakni ideologi. Setiap wacana memiliki ideologi dominan yang dapat berpengaruh terhadap suatu wacana. Wacana bukan suatu yang netral dan berjalan alamiah. Pada analisis wacana, bahasa tidak diposisikan secara tertutup akan tetapi perlu dilihat juga bagaimana ideologi beperan dalam membentuk wacana.

\section{Metode Penelitian}

Metode penelitian yang digunakan adalah deskriptif kualitatif, mengingat data yang digunakan adalah berupa katakata, paragraf, dan wacana. Penelitian ini mendeskripsikan masalah yang ditemukan pada dokumen, masalah tersebut kemudian dianalisis dan ditafsirkan sesuai data yang ada. Dokumen yang diteliti adalah tulisan yang diunggah di grup Facebook Komunitas Bisa Menulis, yaitu cerita bersambung Lelaki Jahanam karya Novie Purwanti (2019).

Pada penelitian ini, data dikumpulkan dengan teknik baca, catat, mengelompokkan data kemudian diaanalisis. Peneliti terlebih dahulu membaca sumber dokumen secara berulang-ulang untuk menemukan bagian-bagian yang menggambarkan representasi perempuan, mencatat dialog 
atau kutipan dan mengelompokkan data yang berkaitan dengan topik kajian yang akan diteliti kemudian dianalisis. Penelitian ini akan dianalisis menggunakan analisis wacana kritis prespektif Fairclough. Analisis wacana kritis dalam penelitian ini menggunakan prinsip-prinsip yang dikemukanan Fairclough yakni meliputi tiga prinsip, (1) prinsip tindakan, (2) prinsip kekuasaan, dan (3) prinsip ideologi untuk mengategorikan data penelitian. Adapun ketiga prinsip tersebut digunakan untuk menguraikan wacana tentang kekuasaan, ideologi dan tindakan yang melingkupi tokoh perempuan dalam Cerbung Lelaki Jahanam. Model analisis wacana kritis digunakan dalam penelitian ini mengingat bentuk data secara keseluruhan adalah berupa paragraf-paragraf dan wacana. Sahidin (2012: 93) menyatakan bahwa menganalisis dengan prespektif analisis wacana kritis memerlukan proses pemahaman terhadap kata dan kalimat pada wacana secara analitis.

\section{Pembahasan}

Seperti yang dipaparkan dalam kajian teori, representasi erat kaitannya dengan suatu konsep yang disebabkan karena adanya budaya di lingkungan masyarakat. Representasi dapat didefinisikan sebagai produksi makna yang berwujud bahasa. Representasi merupakan suatu proses sosial yang dapat dimaknai dengan sistem tanda seperti teks, fotografi, dialog, video, film, dan lainnya.

Lelaki Jahanam merupakan cerita bersambung yang ditulis oleh Novie Purwanti. Kisah yang diceritakan Novie Purwanti ini banyak dipengaruhi oleh kenyataan di dalam lingkungan sosial masyarakat. Cerita yang disajikan erat kaitannya dengan kondisi masyarakat perkotaan yang bebas dalam hal pergaulan. Tidak hanya bercerita tentang pergaulan masyarakat kota, akan tetapi juga disajikan kisah masyarakat desa. Pengisahan pada cerbung Lelaki Jahanam difokuskan pada kisah-kisah tokoh perempuan di dalamnya, mengenai kedudukan perempuan yang digambarkan dalam cerbung tersebut.

Dalam cerbung karya Purwanti, diceritakan empat tokoh perempuan yang dapat direpresentasikan melalui paragraf cerita yang disajikan. Keempat tokoh perempuan tersebut adalah Tia (perempuan desa), Ibu Tia, Nyonya Dini (perempuan kota) dan Bu Mini (pemilik laundry). Dari keempat tokoh tersebut hanya ada dua tokoh yang ditonjolkan dalam cerbung. Tokoh yang ditonjolkan 
atau dapat disebut sebagai tokoh utama adalah Tia, perempuan desa yang dalam kisahnya merantau ke kota Surabaya untuk menafkahi anaknya karena ditinggal oleh suaminya ketika anaknya masih janin. Selain Tia, tokoh lain yang menonjol adalah tokoh Dini, perempuan yang tinggal di kota besar Surabaya dan hidup bebas dalam pergaulan.

\subsection{Ideologi Gender dalam Merepresentasikan Perempuan Desa}

Sosok Tia diceritakan oleh Novie Purwanti melalui dua bagian dalam cerita. Fase pertama memang diceritakan tentang Tia yang sudah memiliki anak, kemudian diceritakan pula saat Tia remaja. Tia adalah perempuan desa yang mengadu nasib dalam hiruk pikuk lingkungan perkotaan di Surabaya. Masa remajanya yang kelam menjadikannya tegar dalam melawan masalah yang ada.

Perempuan desa identik dengan perilaku yang lemah lembut dan hormat kepada siapapun. Pada cerbung tersebut, Tia (perempuan desa) digambarkan sebagai sosok perempuan yang polos. Penggambaran sosok Tia ketika remaja terlihat jelas tentang bagaimana posisi gadis desa yang lugu. Hal ini tergambar dalam pengisahan asmara Tia dengan Wahyu.
(1) Akal sehatnya menyuruh menolak ajakan dari pria asing tak dikenal. Tapi, kebodohan yang menang.

(2) Tia tersenyum penuh kebahagiaan. Membayangkan akan berkencan dengan pria sekeren artis. Gadis desa sepertinya tak akan mendapatkan kesempatan kedua, jadi dia harus benar-benar memanfaatkannya. Tak peduli orang mau bilang apa.

Kutipan data poin (1) di atas menggambarkan kepolosan perempuan desa. Tia sebagai remaja yang baru saja mengenal asmara, membuatnya terlena dengan nafsu dan keinginannya. Kutipan data poin (2) pada kalimat Gadis desa sepertinya tak akan mendapatkan kesempatan kedua, jadi dia harus benarbenar memanfaatkannya. Tak peduli orang mau bilang apa hal ini dapat menggambarkan bahwa sebagai gadis desa, Tia merasa mendapatkan kebahagiaan tersendiri mengenal laki-laki kota yang tampan. Tidak semua temannya merasakan apa yang ia rasakan.

Kepolosan Tia sebagai gadis desa tersebut memberi celah pada laki-laki seperti Wahyu. Dalam hal ini prinsip wacana kekuasaan berperan dalam interaksi sosial Wahyu dan Tia. Wahyu memanfaatkan kepolosan Tia untuk kebahagiaan dirinya. Pada akhirnya 
Wahyu berniat melamar Tia untuk dijadikannya sebagai istri.

(3) "Maukah kamu jadi istriku, Dek Tia?"

"Mas Wahyu jangan bercanda. Kita baru saja kenal. Baru lima hari kenal. Kenapa tiba-tiba ingin menikah?"

"Aku yakin kamu gadis baik, Tia. Kapan lagi bisa bertemu dengan calon istri yang sempurna sepertimu. Kesempatan ini nggak akan aku sia-siakan."

Meski pada akhirnya setelah beberapa bulan pernikahan, Wahyu meninggalkan Tia karena tidak tahan dengan kehidupan lingkungan yang ia tinggali. Kebebasan seperti dulu tidak ia dapatkan. Hal tersebut dijelaskan dalam narasi, Berkeluarga ternyata tidak cocok untuknya. Apalagi sekarang, saat perut Tia mulai membesar, layanan ranjang menjadi tak memuaskan. ... Bosan menjadi tahanan, bosan dengan kemiskinan, muak dengan segala kecurigaan Tia dan marah terhadap dunia. Ia ingin kembali, memulai kebebasan yang dulu menjadi nadi hidupnya. Toh, pada dasarnya ia juga tak mencintai wanita yang sekarang menjadi istrinya. Ia hanyalah pelarian yang menyakitkan.

Pada kutipan yang dicetak tebal di atas, menandakan bahwa gender mempengaruhi kehidupan. Antara laki- laki dan perempuan dikotak-kotakkan melalui gender. Dengan demikian, pihak laki-laki menjadi yang berkuasa dan perempuan menjadi termarginalkan. Pada kutipan Toh, pada dasarnya ia juga tak mencintai wanita yang sekarang menjadi istrinya. Ia hanyalah pelarian yang menyakitkan, tampak jelas bahwa perempuan dianggap lemah sehingga mudah untuk dipermainkan. Hal tersebut menandakan bahwa laki-laki menjadi superior, berkuasa terhadap perempuan. Perempuan dianggapnya hanya sebagai pemuas nafsu belaka.

Hal di atas sejalan dengan pendapat yang dikemukakan oleh Syam (2011: 9) mengenai posisi perempuan berdasarkan gender. Posisi perempuan kerap disimbolkan sebagai suatu kehalusan, sesuatu yang bergerak lamban dan emosional. Perempuan lekat dengan idiom-idiom seperti keterpurukan, ketertindasan, bahkan konsep yang telah telanjur diterima masyarakat adalah bahwa perempuan adalah objek bagi kaum laki-laki. Termasuk dalam norma tentang seksualitas, laki-laki dianggap paling dominan dorongan seksualnya, perempuan lebih pasif dan reseptif.

\subsection{Representasi Perempuan dalam Melawan Ideologi Patriarki \\ Sebagaimana yang telah dipaparkan} dalam kajian teori bahwa persoalan 
wacana serta ideologi yang berkembang di lingkungan sekitar dapat dipecahkan dengan representasi. Hal serupa juga terlihat pada penggambaran lain mengenai sosok Tia tentang bagaimana Tia melawan ideologi patriarki yang ada di lingkungan masyarakatnya. Ideologi patriarki masih berlaku dalam lingkungan keluarganya. Hal ini tampak pada narasi dan dialog berikut.

(4) $\mathrm{Bu}$ Kanti membelai rambut Tia yang meriap tak beraturan. Ia mengambil segelas teh hangat, menyodorkan kepada putrinya yang duduk lemas di ruang tamu. Tia menolaknya. Mendorong gelas sambil menggelengkan kepala.

"Kalau kamu seperti ini terus akan kukawinkan sama Pak Sutris, duda tua bekas RT, lho."

"Emak! Siapa yang mau sama orang tua itu. Meskipun kaya, dia penyakitan." Tia segera mengambil teh dari tangan Ibunya. Ia meminumnya sampai habis. Kehangatan menjalari tubuh gadis itu.

Pada kutipan di atas dapat digambarkan bahwa perjodohan masih berlaku di lingkungan masyarakat desa yaitu dengan kutipan "Kalau kamu seperti ini terus akan kukawinkan sama Pak Sutris, duda tua bekas RT, Iho". Namun, Tia mengupayakan agar dirinya tidak dinikahkan dengan laki-laki di desanya. Keinginan Tia untuk menikah dengan laki-laki kota diupayakan dengan mempengaruhi bapaknya melalui dialog "Mak, Pak, anakmu ini sudah dilamar. Aku mau nikah sama Mas Wahyu." Tetapi hal tersebut mendapat penolakan secara halus dari bapaknya, mengingat umur Tia yang masih belia "Biar Bapak pikirkan dulu, Nduk. Ditimbang baik buruknya". Meski mendapat penolakan dari bapaknya, Tia tetap ngotot dan berusaha membujuk bapaknya.

(5) "Ayolah, Pak. Aku sudah cocok sama Mas Wahyu." Tia menatap kedua orangtuanya memohon. Bagaimanapun, Wahyu harus menjadi suaminya. Ia akan menerjang badai, asalkan tujuannya tercapai. Gigih Tia merayu Bapaknya. Segala macam cara ia gunakan. Gadis itu mendadak rajin membantu di warung. Memijiti tubuh Emak Bapaknya ketika warkop sepi. Ia juga membersihkan area rumah sampai kinclong. Nyaris tak membantah apapun yang diperintah orang tuanya.

Kutipan di atas sejalalan dengan prinsip wacana prespektif Fairclough yakni wacana dipandang sebagai sesuatu yang bertujuan. Kutipan dialog dan narasi tentang tokoh Tia di atas merupakan suatu tindakan yang dilakukan Tia untuk mempengaruhi, membujuk meyakinkan bapaknya. Menikah bukanlah perkara hal yang mudah dijalani untuk seusia tokoh Tia yang masih sangat muda, 19 tahun. 
(6) Selama 19 tahun hidupnya, saat inilah puncak kebahagiaan. Sekejap, Tia ingin Wahyu menjadi pacarnya. Bukan, tapi menjadi suaminya. Ia mulai membayangkan hidup bahagia selamanya bersama lelaki idaman. Mempunyai banyak anak dan bersama mengelola usaha penginapan di tanah jatah warisannya.

(7) Cinta polos seorang gadis desa yang menitipkan seluruh hatinya kepada pemuda serupa dewa.

Kutipan data (6) di atas menggambarkan keputusan yang diambil Tia hanya berdasarkan keinginannya terutama pada kata Sekejab. Kemudian pada penggalan cerbung kutipan data (7) merupakan penggambaran perasaan cinta oleh Tia yang didasari dengan keinginan semata.

Pada cerbung karya Novie Purwanti diceritakan bahwa Wahyu yang telah menyatakan cinta kepada Tia dan mengajak Tia menikah, ia pergi begitu saja tanpa pamit. Kemudian diceritakan pula bahwa Wahyu menepati janjinya untuk menikahi Tia dengan benar-benar datang ke rumah orangtua Tia untuk melamar. Lamaran ini lagi-lagi mendapat keraguan dari bapak Tia dengan mengajukan syarat "Tia adalah anak kami satu-satunya. Dia yang akan merawat kami di hari tua. Jadi, meskipun setelah menikah, Tia akan tetap tinggal di sini. Mungkin terdengar egois, tapi itulah syarat meminang Tia. Kalau kamu setuju, maka saya akan menerima lamaranmu". Dari syarat yang diajukan bapak Tia kepada Wahyu, Wahyu meyetujuinya dengan tanpa ragu "Saya setuju, Pak," ucap Wahyu tanpa ragu.

Perhelatan yang megah dan rela mengorbankan harta untuk pesta perikahan juga tampak dari kebudayaan orang-orang desa dengan kutipan Dua bulan kemudian, mereka menikah. Pak Nyoto menggadaikan surat tanah dan rumah untuk menanggap orkes pantura. Pernikahan putri satu-satunya sangat meriah namun meninggalkan tupukan utang. Hasil kotak amplop tidak cukup untuk melunasi semuanya. Satu-satunya harta paling berharga yang dimilki orang desa adalah tanah luas. Hajatan dikatakan besar jika orang desa mampu untuk menyuguhkan penampilan orkes dangdut atau musik lain di hajatan yang mereka rayakan.

Meski Tia dan Wahyu akhirnya menikah, namun cerita yang disajikan oleh Novie Purwanti dalam kisah asmara antara Wahyu dan Tia setelah menikah diceritakan menyakitkan. Selang beberapa bulan menikah dan Tia dikaruniani anak yang masih dalam kandungan, Wahyu meninggalkan Tia. 
Yuwono, (2018: 106) berpendapat bahwa masyarakat Indonesia masih kental akan budaya patriarki, sehingga perempuan ditempatkan pada posisi di bawah laki-laki dan ditempatkan pada posisi yang lebih mengutamakan ranah domestik. Dalam kepengurusan rumah tangga, beban perempuan lebih besar dibandingkan laki-laki.. Kegiatan perempuan sebagai pencari nafkah hanya dianggap sebagai peran sekunder, sementara posisi laki-laki lebih leluasa karena sering dikaitkan dengan publik yaitu segala urusan yang ada di luar rumah. Dalam hal ini, Sosok Tia berusaha melawan ideologi patriarki yaitu terkait dengan perannya dalam sektor publik utuk mencari nafkah tergambarkan pada narasi berikut.

(8) Satu bulan lalu, Tia nekat merantau ke kota. Sebenarnya Emak dan Bapaknya melarang. Namun, wanita berkulit sawo matang itu bersikeras hendak mengadu nasib di Surabaya. Dengan berbekal kemauan, Tia berangkat naik bis menuju kota yang konon bisa mewujudkan mimpi-mimpi. Satusatunya mimpi Tia adalah memberikan kehidupan yang layak untuk putranya.

Pada kalimat ...Tia nekat merantau ke kota. Sebenarnya Emak dan Bapaknya melarang. Namun, wanita berkulit sawo matang itu bersikeras hendak mengadu nasib di Surabaya tampak digambarkan bagaimana upaya Tia untuk mengubah kehidupannya. Dari kutipan tersebut juga merepresentasikan upaya perempuan untuk melawan pandangan patiarki masyarakat desa bahwa perempuan tidak dapat mengaktualisasikan diri dalam ranah publik.

Wacana budaya patriarki yang berkaitan dengan prinsip wacana tentang ideologi prespektif Fairclough tampak pada kisah kehidupan Tia. Kehidupan masyarakat desa yang melingkupi tokoh Tia tidak jauh dari budaya ptriarki yang memandang lemah perempuan.

\subsection{Representasi Perempuan Berdasarkan Status Sosial \\ Penggambaran mengenai} perempuan dilihat dari status sosial tampak pada tokoh Dini. Tokoh Dini merupakan perempuan kota yang ambisius dan dapat melakukan hal apapun untuk mendapatkan apa yang diinginkan meski dengan jalan yang tidak benar. Dini direpresentasikan sebagai wanita yang egois dan rela melakukan apapun untuk membuat dirinya bahagia.

Wahyu sudah berpakaian lengkap, duduk di sofa warna gading sambil meneguk soda. Memperhatikan tubuh Dini di bawah selimut. Wanita kesepian yang rela merogoh kocek dalam-dalam untuk dipuaskan. 
(9) Empat tahun lalu, mereka bertemu di klub malam tempatnya bekerja. Wahyu hapal dengan ekspresi wanita yang butuh pelampiasan. Dengan mudah dia mendapatkan tubuh dan uang Dini.

(10) Sebetulnya Wahyu merasa kasihan dengan wanita itu. Menyerah dengan keadaan suaminya dan memutuskan untuk mencari kesenangan dengan pria lain. Sama seperti wanita-wanita kaya lainnya, meskipun suami mereka tak punya masalah dengan urusan ranjang, tapi masih penasaran dengan lelaki lain.

Kutipan data (10) yang dicetak tebal menggambarkan bagaimana kultur yang terdapat pada diri wanita-wanita kaya seperti Dini. Status sosial dalam masyarakat mempengaruhi perilaku Dini. Dini membeli kebahagiaan biologis dari laki-laki bernama Wahyu. Sifat yang demikian menandakan adanya keinginan untuk disamakan dengan laki-laki jalang. Sebab musabab Dini rela membayar lakilaki lain sebagai sumber kebahagiaan bagi dirinya adalah karena suaminya, Zain yang mengidap penyakit sehingga Dini sudah tidak mendapatkan kebahagiaan biologis dengan Zain.

Psikolog Mira Rumeser pada artikel yang ditulis Erwin dalam Tempo.co (2010) menyatakan bahwa perempuan yang menyewa jasa laki-laki sebagai gigolo pada umumnya adalah perempuan yang kesepian dan mempunyai banyak uang, tetapi dalam kehidupannya tidak menemu kata bahagia. Pada umumya, yang dicari tidak hanya kepuasan seksual, akan tetapi juga sebagai penawar rasa kesepian tersebut.

Kehidupan masyarakat kota yang cenderung hedon, memang bebas dan masyarakat di dalamnya sama-sama acuh. Hal ini dinarasikan dalam cerbug tersebut dalam sudut pandang tokoh Tia.

(11) Ketika Zain pergi, selalu ada seseorang yang menemani Dini. Pernah sekali Tia mengintip dari balik jendela. Beberapa orang turun dari mobil, mereka berpesta, terbukti dengan banyaknya camilan dan botol alcohol kosong berceceran... Orang sekitar perumahan sepertinya sudah terbiasa dengan ulah keluarga majikannya. Tak ada yang mengeluh, mereka asyik dengan urusan masing-masing dan enggan mengingatkan tetangga. Hidup menyepi di dalam istananya. Tia hanya bisa membatin, bungkam seribu bahasa. Kedudukan rendahan sepertinya tidak akan pernah digubris seandainya memberi nasehat. Bisabisa dia diusir bila nekat berceramah di hadapan Dini.

Pada sebuah perkawinan jika salah satu individu ada yang merasa tidak mendapatkan kebahagiaan, maka ia berhak untuk meminta berpisah dan mencari kebahagiaannya sendiri. Hal tersebut tampak pada perilaku Dini. 
(12) "Berhenti! Dasar lelaki impoten!"

Kali ini, teriakan Dini berhasil menghentikan langkahnya. Setiap

kali bertengkar, kata-kata mematikan itu selalu keluar dari mulut wanita yang telah dinikahinya selama empat belas tahun. Biasanya Zain akan membiarkan dan menghindarinya. Namun, saat ini ada orang lain. Zain begitu tak nyaman rahasianya terbongkar tepat di hadapan Tia.

"Aku memang sudah cacat, Dini. Silakan lakukan apa pun maumu." Tanpa berbalik, Zain menghamburkan kata-kata bernada dingin.

Pengisahan rumah tangga Dini dan Zain digambarkan Novie Purwanti tidak harmonis, disamping karena penyakit Zain, penyebab lainnya adalah keegoisan dari masing-masing tokoh Dini dan Zain. Zain sebagai laki-laki memilih untuk membiarkan sikap Dini dan memilih untuk pergi meghidar daripada menasehati Dini. Begitupun Dini, ia masih kukuh dengan kehidupan liarnya dan enggan membicarakan masalah tersebut dengan Zain secara baik-baik.

Penggambaran lainnya tentang tokoh Dini adalah ia merupakan perempuan bertipe ambisius dan dapat melakukan hal apapun untuk mendapatkan apa yang diinginkan meski dengan jalan yang tidak benar. Diceritakan di halaman 73 bahwa Dini melukai Wahyu dengan menyewa orang untuk mencelakakan Wahyu.

Dini membusukkan diri dengan menghajar mantan lelaki simpanannya sampai hampir mati. Perempuan kalau sudah sakit hati bisa nekat melakukan sesuatu yang mengerikan.

(13) Ya, Dinilah yang berada di balik insiden berdarah itu. Tanpa malu, perempuan laknat itu pura-pura simpatik dengan datang menjenguk Wahyu. Ternyata semua hanya sandiwara. Bukan watak Dini untuk menyerah. Dia selalu mendapatkan apa yang diinginkan. Bila Gagal, maka tak seorang pun yang boleh memiliki mangsanya. Tia mengepalkan tangan. Mendengarkan tuturan petugas.

Gambaran lainnya mengenai tokoh Dini, ia juga digambarkan sebagai perempuan yang mengutamakan penampilannya. Hal ini terlihat dari penggalan cerbung yang menceritakan bahwa penampilan Dini masih tampak muda, bau harum tubuhnya semerbak setiap kali ia akan keluar rumah. Hal ini tampak melalui kutipan berikut.

(14) Sepuluh menit kemudian, Dini keluar. Aroma sabun menguar dari kulit putihnya. Tanktop gelap dan celana jeans selutut membalut tubuh padat berisi.

Permanadeli (2015:

memaparkan bahwa pada ekspresi verbal, 
secara umum penampilan mengacu pada apa yang dapat dilihat. Penampilan sebagai suatu tindakan berhias diri memiliki nilai sosial dan moral serta mempersoalkan perasaan dari yang melihat tentang individu dan sosial, lahir dan batin, kasar dan halus, atau fana dan semesta. Dalam hal ini, representasi status sosial pada tokoh Dini dapat dilihat dari pakaian yang ia kenakan.

(15) Seorang wanita beralis tebal keluar. Dia memakai hot pants yang memperlihatkan gumpalan lemak pada pahanya. Tia heran, apakah pembantu sekarang berpenampilan berani seperti itu?

"Saya mengantar baju atas nama Nyonya Dini."

"Iya, betul. Aku Nyonya Dini.

Selain gambaran mengenai penampilan, gambaran lain dari tokoh Dini yang diceritakan oleh Novie Purwanti adalah mengenai sikapnya sebagai bos. Sikap Dini yang sering membawa laki-laki ke rumahnya berusaha dinasihati oleh Tia, akan tetapi Tia sadar atas kedudukannya di rumah itu. "Apa gunanya pendapat pembantu rendahan seperti saya, Nyonya?" Hal tersebut dipertegas dengan dialog dini "Betul juga katamu. Buat apa aku minta pendapatmu. Kalau begitu, lakukan tugasmu dengan baik. Akhir minggu nanti akan kutambahi bonus."
Mengenai tokoh Tia pada tataran sosial ini, Tia sebagai pembantu memang menyadari kedudukannya, akan tetapi dengan melihat keadaan rumah tangga majikannya, sebagai perempuan ia tidak tega melihat keadaan tersebut. Tia berusaha menasihati majikannya tersebut lewat Zain. "Bapak Zain, semua masalah pasti ada jalan keluarnya bila memang ingin menyelesaikan." Akan tetapi nasihat yang diucapkan Tia tersebut mendapat penolakan dari Zain baik berupa tindakan maupun perkataan Zain. Tindakan penolakan Zain tergambar dari narasi ketika Zain berdiri medekati Tia seperti marah. Respon Tia terhadap tindakan tersebut adalah mundur menjauhi Zain dengan wajah memucat. Penolakan Zain melului perkataan tampak pada kutipan, "Tahu apa kamu dengan masalahku? Sebaiknya kamu kerjakan saja tugasmu. Jangan keluar dari batasanmu. Ingat, kamu hanya pembantu di sini." Hal tersebut kemudian titanggapi Tia dengan perkataan, "Memang benar saya hanya pembantu. Tapi bila ada kesalahan, saya harus memberi tahukannya kepadamu, Mas Zain anak Pak Karso!" Tanggapan Tia terhadap penolakan Zain atas nasihatnya juga dilakukan melalui ekspresi Tia ketika mengucapkan kalimat tersebut dengan 
nada suara tinggi dan tatapan mata Tia yang menantang mata Zain.

Pada persoalan di atas sejalan dengan prinsip keempat prespektif Fairclough yakni kekuasaan. Dalam hal ini, kekuasaan yang melingkupi wacana tersebut adalah kekuasaan yang berkaitan dengan kedudukan. Tokoh Zain sebagai majikan Tia memiliki kedudukan di atas Tia. Hal inilah yang kemudian menjadikan Tia sebagai tokoh yang diposisikan rendah. Dapat pula dilihat siapakah yang harus dan boleh berbicara, sementara siapa pula yang hanya mendengarkan dan mengiyakan.

Adapun tokoh perempuan lainnya dalam cerbung Lelaki Jahanam yaitu $\mathrm{Bu}$ Mini sebagai bos laundry di tempat kerja Tia. Tokoh $\mathrm{Bu}$ Mini direpresentasikan positif meski hidup di lingkungan kota dan memiliki kedudukan dalam tatanan sosial.

(16) Dalam gigil, Tia melangkah menuju rumah Dini. Gemetar wanita itu bercerita kepada bos binatu. Takut dengan reaksi yang bisa membuat hatinya berdenyut. Kekhawatiran tak terbukti. Bu Mini melepaskan Tia dengan titik air mata. Ia bahkan mendoakan Tia mendapatkan kebahagiaan di tempat kerja baru.

Bersyukur, hanya itu yang bisa dilakukan. Bertemu orang-orang baik, menolong tanpa pamrih dan saling mendoakan dalam kebaikan.
Penggalan cerbung di atas menjelaskan bahwa sebagai bos yang biasanya digambarkan dengan watak yang negatif akan tetapi sosok Mini ini berbeda dengan anggapan biasanya. Dalam cerita tersebut mini melepaskan Tia yang akan resign dari laundrynya, Bu Mini melepaskan Tia dengan titik air mata. Hal ini merepesentasikan, meski sebagai bos, tapi Bu Mini tidak bertindak sebagai yang memiliki kuasa atas karyawannya. Meski demikian representasi sebagai bos juga dilekatkan tergambar dari penampilan $\mathrm{Bu}$ Mini. Penggambaran penampilan sebagai bos di ceritakan di halaman 2 bahwa sosok $\mathrm{Bu}$ Mini yang bergincu tebal. Bu Mini, bos laundry yang bergincu tebal menyerahkan kresek putih berisi baju yang sudah di setrika rapi pada Tia.

\section{Penutup}

Cerita bersambung karya Novie Purwanti (2019) yang diunggah di grup menulis Facebook, Komunitas Bisa Menulis (KBM) merupakan cerita yang banyak menampilkan representasi perempuan saat ini. Representasi tersebut ditunjukkan melalui ideologi yang mempengaruhi kedudukan perempuan dalam lingkungan masyarakat. Dari pembahasan yang telah dilakukan, penulis 
menyimpulkan bahwa representasi Maret.

dipengaruhi karena adanya gender, representasi perlawanan perempuan dari adanya ideologi patriarki, dan representasi dilihat dari status sosial perempuan. Ketiga hal tersebut digambarkan pada tokohtokoh perempuan dalam cerbung Lelaki Jahanam.

\section{Daftar Pustaka}

Aprinta E.B, G. 2011. Kajian Media Massa: Representasi Girl Power Wanita Modern Dalam Media Online (Studi Framing Girl Power dalam Rubrik Karir dan Keuangan Femina Online). The Messenger, 11(2), 1227.

Eriyanto. 2001. Analisis Wacana: Pengantar Analisis Teks Media. Yogyakarta: Lkis.

Erwin, Z. 2010. Perempuan Jadikan Gigolo Sebagai Peliharaan. Diakses pada 10 Oktober 2020, dari https://gaya.tempo.co

Fairclough. 1995. Media Discourse. New York: Edward Arnold.

Fairclough. 1996. Language and Power. New York: Longman Inc.

Irawan, R. E. 2014. Representasi Perempuan dalam Industri Sinema. Humaniora, 5(1), 1-8.

Isnaniah, S. 2014. Representasi Ajaran Islam dalam Novel-novel Karya Habiburrahman El Shirazy (Kajian Sosiologi Sastra dan Nilai-nilai Pendidikan). Universitas Sebelas
Kelana, I. 2018. Era Digital Berdampak Besar terhadap Dunia Kepenulisan. Diakses pada 3 Oktober 2020, dari http://m.republika.co.id

Lisnawati, I. 2017. Cerita Pendek Nyanyian Daun Teh dalam Tinjauan Analisis Wacana Kritis. Semantik, $3(1), 62-85$.

Mahmudah, R. 2019. Penggambaran Perempuan Arab Saudi oleh Media Daring (Analisis Wacana Kritis Fairclough pada Media Al-Jazair Online dan Al-Madina). Yogyakarta: UIN Sunan Kalijaga.

Micarina, K. 2015. Perempuan dan Sastra. Diakses pada 1 Oktober 2020, dari https://www.kompasiana.com

Permanadeli, R. 2015. Dadi Wong Wadon Representasi Sosial Perempuan Jawa di Era Modern. yogyakarta: Pustaka Ifada.

Prasanti, D., \& Janitra, P. A. 2016. Representasi Perempuan dalam Iklan "Fair And Lovely" Versi Nikah atau S2. Jipsi, 6(1), 47-66.

Purwanti, N. 2019. Lelaki Jahanam. Diakses pada 3 September 2020, dari

https://mobile.facebook.com/groups/ 488655531196343?group_view_refer rer $=$ profile_browser

Sahidin, D. 2012. Teknik Critical Discourse Analysis (CDA) pada Pembelajaran Cerpen. Semantik, 1(1), 91-105.

Sanusi, Insani Nur Citra, \& Bahfiarti, T. 2018. Representasi Perempuan dalam 
Representasi Perempuan dalam...

Film Dangal (Sebuah Analisis Diskursus Kritis). Komunikasi KAREBA, 7(2), 212-218.

Setiawan, S., \& Halum, Y. S. 2016. Pesan dari Slebor: Analisis Wacana Kritis Terhadap Fenomena Bahasa Tulis Stiker Sepeda Motor. Paramasastra, 3(2), 172-196.

Sugihastuti, \& Saptiawan, I. H. 2010. Gender dan Inferioritas Perempuan: Praktik Kritik Sastra Feminisme. Yogyakarta: Pustaka Pelajar.

Surahman, S. 2014. Representasi Perempuan Metropolitan dalam Film 7 Hati 7 Cinta 7 Wanita. Komunikasi, 3(1), 39-63.

Syam, T. A. N. 2013. Representasi Nilai Feminisme Tokoh Nyai Ontosoroh dalam Novel Bumi Manusia Karya Pramoedya Ananta Toer (Sebuah Analisis Wacana). Makassar: Universitas Hasanuddin.

Yuwono, N. P. 2018. Perempuan dalam Kungkungan Budaya Patriarkhis. Muwazah, 10(2), 96-115. 